Proc. Estonian Acad. Sci. Geol., 2003, 52, 4, 199-212

\title{
The new early Palaeozoic rugose coral genera Eurogrewingkia gen. nov. and Fosselasma gen. nov.
}

\author{
Björn E. E. Neuman \\ Strandvägen 25, SE-652 17 Karlstad, Sweden; bneuman@mypost.se.com \\ Received 3 March 2003, in revised form 9 May 2003 \\ Abstract. The new genus Eurogrewingkia gen. nov. (type species selected here is Grewingkia \\ bilateralis Neuman, 1969) is erected for streptelasmatid rugose corals with Grewingkia-like ontogeny \\ lacking a cardinal fossula sensu stricto. In addition, the new genus Fosselasma gen. nov. (type species \\ selected here is Streptelasma unicum Neuman, 1975) is erected for species with a Streptelasma-like \\ ontogeny but provided with a cardinal septofossula. Species of Eurogrewingkia are currently \\ recognized from the Upper Ordovician, Rawtheyan-Hirnantian strata in Europe and North America. \\ Species of Fosselasma are found only in Hirnantian strata in Sweden and Norway.
}

Key words: taxonomy, rugose corals, Upper Ordovician, Rawthyean, Hirnantian.

\section{INTRODUCTION}

Comparatively few coral specialists have been concerned about detailed taxonomy, morphology, ontogeny, and palaeoecology of the relatively simply constructed Ordovician and Early Silurian solitary rugose corals, and a great number of taxa are either undescribed or too little known. Bulk studies of specimens of easily identified species have, however, revealed that some morphological features are less variable than others, and are more stable signatures as a basis for reliable taxonomy.

Recent re-examinations of some of my earlier described taxa (Neuman 1969, 1975,1986 ) have shown that, due to re-evaluation of some morphological features, alteration of the taxonomy is necessary. Fossular structures, including a fossula sensu stricto or a septofossula (Neuman 1984, p. 122, fig. 2), are revealed as important morphological features on the generic level. Unfortunately, several rugose coral genera include a great variety of species with fairly different morphology. Other genera, on the contrary, may be so narrowly specified that new species are not always recognizable. One of the most problematic genera is Streptelasma Hall, 1847. 
Although the lectotype of the type species Streptelasma corniculum Hall, 1847 is fairly well described and illustrated (Neuman 1969, pp. 10, 11, figs. 4-6), species having quite different morphological features have become included in this genus also after 1969. These are the reasons why the new genera Eurogrewingkia and Fosselasma are here erected for some species earlier assigned to Grewingkia Dybowski, 1873 and Streptelasma Hall, 1847.

Kaljo (1961, pp. 54-59, pls. 1-3) gave the first modern re-description (in Russian) of G. buceros (Eichwald, 1856) and defined Grewingkia as a subgenus under Streptelasma. He also described Streptelasma (Grewingkia) europaeum Roemer, 1861 and S. (G.) europaeum hosholmensis Kaljo, 1961, as well as his new genus Rectigrewingkia Kaljo (1961, pp. 62, 63). Neuman (1969) described the following species of Grewingkia: G. buceros (Eichwald, 1856), G. contexta Neuman, 1969, G. bilateralis Neuman, 1969, and G. anguinea (Scheffen, 1933). Additionally, the genus Densigrewingkia Neuman, 1969 was erected (Neuman 1969, pp. 51-53, figs. 43, 44), and the range of variation concerning the morphological structures within the genus Grewingkia was discussed and illustrated (Neuman 1969, pp. 33-35, fig. 27, and table 2).

Recent re-examination of the holotype (= monotype) of Grewingkia buceros (Eichwald, 1856) by the present author has revealed that this species is not synonymous with Kiaerophyllum kiaeri Wedekind, 1927 as earlier thought by Neuman (1969, pp. 36-38), although these species are very similar. Consequently, the emended species Kiaerophyllum kiaeri Wedekind, 1927 is re-established as a species under Grewingkia. Morphologically, both G. buceros and G. kiaeri are more closely related to the great number of North American species of Grewingkia provided with a pronounced cardinal fossula (thoroughly described by Elias in numerous papers, e.g. 1981, 1982, 1985), e.g. G. robusta (Whiteaves, 1896), G. canadensis (Billings, 1862), G. deltensis Elias, 1982, and G. rustica (Billings, 1858) than to the pseudofossulate species also assigned to Grewingkia. The consequences of the present observations are that species of Grewingkia with a fossula sensu stricto are correctly classified under the genus Grewingkia Dybowski, 1873. All species having only a more or less pronounced cardinal pseudofossula are herein transferred to the new genus Eurogrewingkia gen. nov. based on the herein selected type species Grewingkia bilateralis Neuman, 1969 (Neuman 1969, pp. 39-43, figs. 31-33).

Detailed research of well-preserved specimens has also clearly shown that both Rectigrewingkia Kaljo, 1961 (see Neuman 1984, pp. 124, 125) and Densigrewingkia Neuman, 1969 (see Neuman 1998, p. 97) are lambelasmatid genera having monacanthine septa.

Neuman (1969, pp. 11-17) assigned Dybowskia prima Wedekind, 1927 to the genus Streptelasma Hall, 1847 and revealed that all species of Dybowskia described by Scheffen (1933) from the locality Stavnestangen (= Stamnestangen) in the Ringerike area, Oslo Region, Norway, are synonymous with Streptelasma primum (Wedekind, 1927). Similar Upper Ordovician specimens from the Siljan District and Östergötland (Sweden) were by Neuman (1969) also included in S. primum. Later Neuman (1975) observed that the Swedish specimens from the "Dalmanitina Beds or 
Lowermost Llandoverian Beds" (most probably corresponding to the Hirnantian Loka Formation erected by Bergström \& Bergström (1996)) are provided with a septofossula, and he erected the new species Streptelasma unicum Neuman, 1975 for those (Neuman 1975, pp. 353-358, figs. 15-17). Due to the importance of fossular structures as signatures on the generic level, the genus Fosselasma gen. nov. is here erected with Streptelasma unicum Neuman, 1975 as the selected type species.

\section{MATERIAL AND METHODS}

All specimens mentioned or illustrated in this paper are preserved either in the collections of The Swedish Museum of Natural History, Department of Palaeozoology in Stockholm, and are marked with RM Cn and registration number, or in the Palaeontological Museum, University of Uppsala, Sweden, and marked UM D and registration number. Specimen R 45321 is preserved in the Palaeontological Department, Natural History Museum in London, U.K. The corals examined are mostly sectioned while thin sections and dry peel sections were made using the same methods as described by Neuman (1969, p. 4). The terminology used mainly corresponds to that given by Hill (1981) and Neuman (1969). The term "septofossula" was introduced by Neuman (1984, pp. 122, 123, fig. 2) where he also discussed other morphological structures.

\section{SYSTEMATIC PALAEONTOLOGY}

Suborder STREPTELASMATINA Wedekind, 1927

Family STREPTELASMATIDAE Nicholson, 1889

Subfamily STREPTELASMATINAE Nicholson, 1889

\section{Genus Eurogrewingkia gen. nov.}

Derivation of the name. After Europe.

Type species. Grewingkia bilateralis Neuman, 1969 (Neuman 1969, pp. 39-43, figs. 31-33).

Type stratum and locality. Upper Ordovician Boda Limestone; Osmundsberg (NE Quarry), Siljan district, Sweden.

Species. Kiaerophyllum anguineum Scheffen, 1933 (= Grewingkia anguinea (Scheffen, 1933), described by Neuman (1969, pp. 48-50, figs. 39-41) from the Rawtheyan (beds 5a), Oslo Region, Norway; the North American species Grewingkia callahanensis Elias, 1984 from the Ashgillian, eastern Klamath Mountains, California; Grewingkia penobscotensis Elias, 1982 from the Ashgillian, County of Maine. 
Diagnosis. Solitary streptelasmatid corals with ceratoid, trochoid or cylindrical corallite. Cardinal side convex. Apex curved, having or lacking holdfast structures, indicating a fixosessile or liberosessile life strategy. Calice moderately deep to shallow and provided with a calicular boss of various height. Axial structure prominent, consisting of several septal lobes and lamellae, having or lacking a median lamella. Septa of fibro-normal type are comparatively little dilated throughout the ontogeny, mainly somewhat more in talonized species in the attachment zone. A cardinal fossula is lacking, but a narrow pseudofossula may be present. Tabulae are mostly complete, and of convex type; peripheral tabellae are mostly few or lacking.

Remarks. Eurogrewingkia gen. nov. differs in the following respects from Grewingkia Dybowski, 1873, which is the most similar genus. Eurogrewingkia gen. nov. is lacking genuine fossular structures and only a cardinal pseudofossula might occur. The cardinal septum is of the same length as the other major septa. Septal dilations are weak or moderate throughout the ontogeny and interseptal chambers are normally present. Tabulae are complete and of uniform convex type, lacking or having few tabellae or complementary plates. The species included are mostly small or mediumsized. The genus Grewingkia Dybowski, 1873, on the contrary, mainly includes comparatively large, liberosessile species with strongly dilated septa throughout the early ontogeny, a cardinal fossula often provided with a septofossular stage (= short cardinal septum) in the calice, and a tabularium with several peripheral tabellae. Other fossulate genera very closely related to Grewingkia are Bighornia Duncan, 1957 and Lobocorallium Nelson, 1963, which mainly differ in having lobated corallites. Additionally, Bighornia has a concave cardinal side. The genera Rectigrewingkia Kaljo, 1961 and Densigrewingkia Neuman, 1969 differ from Eurogrewingkia gen. nov. in being lambelasmatid corals with monacanthine or monacanthate septal structure. Grewingkia contexta Neuman, 1969 (Neuman 1969, pp. 43-48, figs. 34-38) is in many ways similar to the other species, here included in Eurogrewingkia gen. nov. New studies have, however, revealed that many specimens of $G$. contexta have depressed tabulae close to the cardinal septum, which should indicate a weak cardinal fossula sensu stricto. In addition, the tabularium includes numerous tabellae, and septa are strongly dilated in the attachment zone of this talonized, fixosessile species. Those are the reasons why the present author still retains G. contexta to the genus Grewingkia Dybowski, 1873.

The North American species Grewingkia callahanensis Elias, 1984 (Elias \& Potter 1984, pp. 1210-1212, figs. 2M-P and 3) and Grewingkia penobscotensis Elias, 1982 (Elias 1982, pp. 72, 73, pl. 12, figs. 1-6; Elias \& Potter 1984, pp. 1209, 1210, figs. $2 \mathrm{H}-\mathrm{L}$ and 3 ), lacking a cardinal fossula or septofossula and only having slightly dilated septa, are here included in Eurogrewingkia.

Occurrence. Species of Eurogrewingkia are recognized from the Upper Ordovician, Ashgillian (Rawthyean-Hirnantian) strata, in Sweden, United Kingdom, and North America. 
Eurogrewingkia bilateralis (Neuman, 1969).

Plate I, figures A-O

1880 Ptychophyllum craigense M'Coy; Lindström in Angelin \& Lindström (partim), p. 35, pl. 1, figs. 19, 20.

?1965 Dalmanophyllum subduplicatum M'Coy; Kaljo \& Klaamann, p. 422, pl. 1, figs. 16-18.

1969 Grewingkia bilateralis Neuman, pp. 39-43, figs. 31-33.

1996 Grewingkia bilateralis Neuman; Somerville (partim), pp. 36, 37, pl. 1, figs. $1 \mathrm{a}, 1 \mathrm{~b}$.

1997 Grewingkia bilateralis Neuman, p. 306.

1998 Grewingkia bilateralis Neuman, p. 95.

Holotype. UM D 1221, figured by Neuman (1969, fig. 31C, G, H, and fig. 32).

Type stratum and locality. Upper Ordovician Boda Limestone, upper part (probably uppermost Rawtheyan or lower Hirnantian); Osmundsberg (NE quarry), Siljan District, Dalarna, Sweden.

Figured specimens. In Neuman (1969): UM D 1220 (fig. 31A, B), UM D 1222 (fig. 31E), UM D 1223 (fig. 31F), RM Cn 54717 (fig. 31D, I, J, and 33A), UM D 1224 (fig. 33A).

Diagnosis. (Mainly after Neuman, 1969, p. 40). Corallite medium-sized (9-30 mm high, largest diameter $11.5-34 \mathrm{~mm}$, and maximum number of major septa 52), trochoid or ceratoid; apex curved with attachment disc and talons on the convex cardinal side. Calice shallow, with low, broad calicular boss, which together with the axial structure has a pronounced median lamella in the cardinal-counter plane. Cardinal septum is as long as the other major septa and situated in a narrow pseudofossula. Tabulae are complete, of convex type with complementary plates, and not very numerous.

Remarks. Grewingkia bilateralis was thoroughly described by Neuman (1969, pp. 39-43, figs. 31-33) and here only some additional information is given. Neuman (1969) did not illustrate any transverse sections made of the lower part of the calice (here presented in Pl. I, figs. A-D), showing the wide axial structure, and the calicular boss with pronounced median septal lamella. A detail of a transverse section (Pl. I, fig. G) is showing the narrow cardinal pseudofossula, the wide axial structure, and the comparatively wide stereozone. A specimen with very thin septa and narrow stereozone is shown in Pl. I, figs. H-N, and the uniform convex tabulae in Pl. I, fig. F. Limited variation concerning the dilations of septa and elements of the axial structure are natural for this species, but open interseptal chambers are always present.

Affinities. Eurogrewingkia bilateralis (Neuman, 1969) is very similar to Dalmanophyllum subduplicatum M'Coy described by Kaljo \& Klaamann (1965, p. 422, pl. 1, figs. 16-18) from the Portrane Limestone, Co Dublin, Ireland (as was also reported 
PLATE I

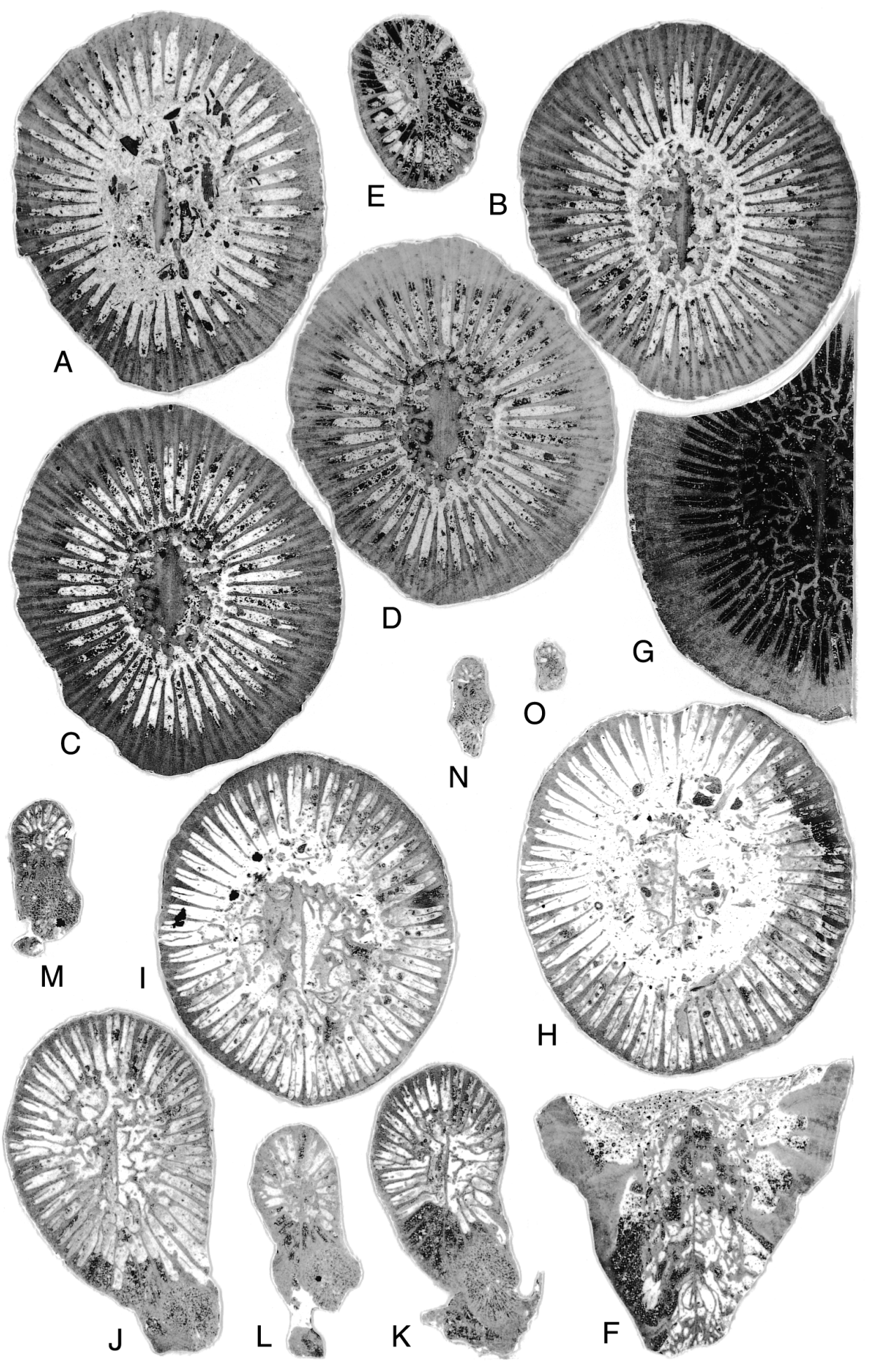


by Neuman 1969, and Somerville 1996). Their description is, however, based on only three silicified specimens, two of which were fragmentary and not illustrated. Specimen R45321 is fairly small, has a rather complete corallite of straight ceratoid shape with a long fixing scar on one side of the apex, and a high calicular boss in the calice. The cardinal septum seems to be as long as the other major septa, and a cardinal fossula is lacking. Dalmanophyllum subduplicatum M'Coy (Kaljo \& Klaamann 1965) seems to be a species of Eurogrewingkia and perhaps conspecific with $E$. bilateralis, which cannot be proved before better preserved topotypic material is collected and examined. Grewingkia bilateralis Neuman, 1969 described and figured by Somerville (1996, pp. 36, 37, pl. 1, fig. 1a, b) from the Chair of Kildare Limestone, Co Kildare, Ireland, seems, due to the figured structures, to be conspecific with E. bilateralis. Somerville (1996, p. 36) reported the presence of only incomplete tabulae but this is denied by the presence of such structures visible in his figured sections. White (pers. comm., 1972) identified Grewingkia cf. bilateralis Neuman, 1969 from the Keisley Limestone (Ashgill), and G. aff. bilateralis Neuman, 1969 from the Conway Castle Grit (Ashgill) of northern Wales. Grewingkia callahanensis Elias, 1984 (in Elias \& Potter 1984, pp. 1210-1212) differs from Eurogrewingkia bilateralis (Neuman, 1969) in having more numerous and more steeply inclined convex tabulae in the axial region, and a median lamella in the axial structure which is not so conspicuously developed during the early ontogeny but is otherwise similar during late stages. Grewingkia penobscotensis Elias, 1982 differs from E. bilateralis (Neuman, 1969) in lacking a median lamella in the axial structure which consists of a few irregular moderately dilated septal lobes and lamellae (Elias \& Potter 1984, pp. 1209, 1210).

Occurrence. Upper Ordovician Boda Limestone, upper part (probably representing late Rawthyean or early Hirnantian age) at the localities Osmundsberg (NE quarry) and Östbjörka, Siljan District, Sweden. Additionally, present in the Chair of Kildare Limestone, Co Kildare, Ireland.

\section{Explanation of Plate I}

Figs. A-O. Eurogrewingkia bilateralis (Neuman, 1969). A-E, RM Cn 69035. Transverse sections through the lower part of the calice showing the wedge-shaped major septa, the axial structure, and the calicular boss with a pronounced median septal lamella and a comparatively wide stereozone. F, UM D 1222. Longitudinal section showing thin convex tabulae (also figured in Neuman 1969, fig. 31E). G, RM Cn 69036. Part of a transverse section showing the wide axial structure with long median lamella and the cardinal pseudofossula with very thin inserted major septa on each side. H-O, UM D 1223. Transverse sections through a medium-sized specimen, in $\mathbf{J}-\mathbf{O}$, showing attachment structures fixed to a bryozoan, the thin septal structures and the narrow (probably eroded) stereozone.

All specimens derive from the Boda Limestone, upper part (Late Rawthyean or early Hirnantian); Osmundsberg (NE quarry), Siljan District, Dalarna, Sweden. All figures are enlarged $\times 3$. Cardinal side is oriented downwards in all transverse sections. 


\section{Genus Fosselasma gen. nov.}

Derivation of the name. After the characteristic fossula.

Type species. Streptelasma unicum Neuman, 1975.

Type stratum and locality. The Upper Ordovician (Hirnantian) Loka Formation; Borenshult, Östergötland, Sweden.

Diagnosis. Solitary streptelasmatid corals with a trochoid, ceratoid or cylindrical corallite. Cardinal side convex. Major septa during the early ontogeny thin, moderately long, seldom reaching the centre of the corallite. During the late ontogeny major septa are comparatively short, leaving a central zone free from septa. A pronounced cardinal septofossula is always present, best visible in the calice. Minor septa of various length; stereozone narrow or moderately wide; tabulae complete and fairly numerous throughout the ontogeny.

Remarks. Fosselasma gen. nov. resembles Streptelasma Hall, 1847 both in morphology and ontogeny but clearly differs in having a septofossula in the late ephebic stage. Fosselasma gen. nov. differs from the septofossulate genus Ullernelasma Neuman, 1975 because the latter genus is lacking complete tabulae and has strongly dilated septa in the early ontogeny.

Species. Streptelasma unicum Neuman, 1975 (type species). Fosselasma sp. nov. (not yet described).

Remarks. Streptelasma subregulare (Savage, 1913), thoroughly re-decribed by McAuley \& Elias (1990, pp. 34-47), shows some similarities with Fosselasma unicum Neuman, 1975 but differs considerably in the following aspects: tabulae are usually depressed in the cardinal fossula (which must be interpreted as a fossula sensu stricto) and septa range from nondilated to completely dilated, which is observed in all ontogenetic stages (also confirmed by Elias, pers. comm.).

Streptelasma schagami Scrutton, 1971 (Scrutton 1971, pp. 208-210, pl. 2, figs. 7-10), having a cardinal fossula sensu stricto visible throughout the ontogeny, differs considerably from Fosselasma gen. nov. also in lacking a septofossula. In this species the cardinal septum is shorter than the other major septa in the neanic stage, but is as long as the other major septa in the ephebic stage. Neither Streptelasma subregulare (Savage, 1913) nor Streptelasma schagami Scrutton, 1971 are species of Fosselasma gen. nov. but ought to be transferred from the nonfossulate genus Streptelasma Hall, 1847 into new fossulate genera.

He (1978) described many species from the Upper Ordovician Guanyinqiao Formation, Guizhou Province, China. These were assigned to Streptelasma, Brachyelasma, and Borelasma and other genera. As observed from the illustrations in He (1978), all these species are provided with a cardinal fossula sensu stricto and seem to have amplexoid septa. Therefore the mentioned fauna does not seem to include any species of Fosselasma. 
A Fosselasma sp. nov. (not yet described) having somewhat longer septa than F. unicum is observed in Hirnantian (5b) strata in the Langesund-Skien area, Oslo Region, Norway.

Occurrence. Upper Ordovician, Hirnantian strata in Sweden and Norway.

Fosselasma unicum (Neuman, 1975)

Plate II, figures A-E

1880 Ptychophyllum craigense M'Coy; Lindström in Angelin \& Lindström (partim), p. 35.

1935 Ptychophyllum craigense M'Coy; Thorslund 1935 (partim), p. 13.

1969 Streptelasma primum (Wedekind); Neuman (partim), pp. 11-17, fig. 7D.

1975 Streptelasma unicum Neuman; Neuman, pp. 353-358, figs. 15-17.

1984 Streptelasma unicum Neuman; Neuman, pp. 122, 123, fig. 2F.

Holotype. Specimen RM Cn 2507. Described and figured by Neuman 1975 (pp. 353-358, figs. 15A-D, 16A-H, and 17).

Type stratum and locality. Upper Ordovician Loka Formation (Hirnantian); Borenshult, Östergötland, Sweden.

Figured specimens. In Neuman (1969, 1975, and 1984) RM Cn 2507, and in Neuman (1975) also RM Cn 59327.

Diagnosis. (Mainly after Neuman 1975, p. 356). Corallite medium-sized or fairly high (at least $80 \mathrm{~mm}$ high, calice diameter at least $22 \mathrm{~mm}$, and the largest number of major septa 49), and of almost straight or irregularly curved (scolecoid) cylindrical type. Calice moderately deep with slightly concave bottom. Pronounced cardinal septofossula present and visible as a calicular pit. In late phases of the neanic stage and in the ephebic stage major septa are comparatively short and axial structure is lacking. Minor septa short; stereozone narrow. Tabulae numerous and complete, during the ephebic stage with horizontal or slightly concave central parts and highly convex margins; during the neanic stage with horizontal or slightly convex central parts.

Remarks. The species was thoroughly described by Neuman (1975, pp. 353-358, figs. 15-17), and very little can be added in this paper. The septofossula, first defined by Neuman (1984, p. 122) and later discussed by Neuman (1993, p. 120) is here added as a new term in the diagnosis. In sub-calicular stages the cardinal septofossula is rather similar to a pseudofossula (lacking distinct tabular depressions). A small fossular pit in the calice, due to the decrease in the length of the cardinal septum, is characteristic of this genus.

Affinities. The few and preliminarily examined incomplete and partly sectioned specimens (from the strata earlier called brachiopod shale or Dalmanitina beds, and probably corresponding to the Loka Formation) from Kullsberg and Nittsjö (Neuman 

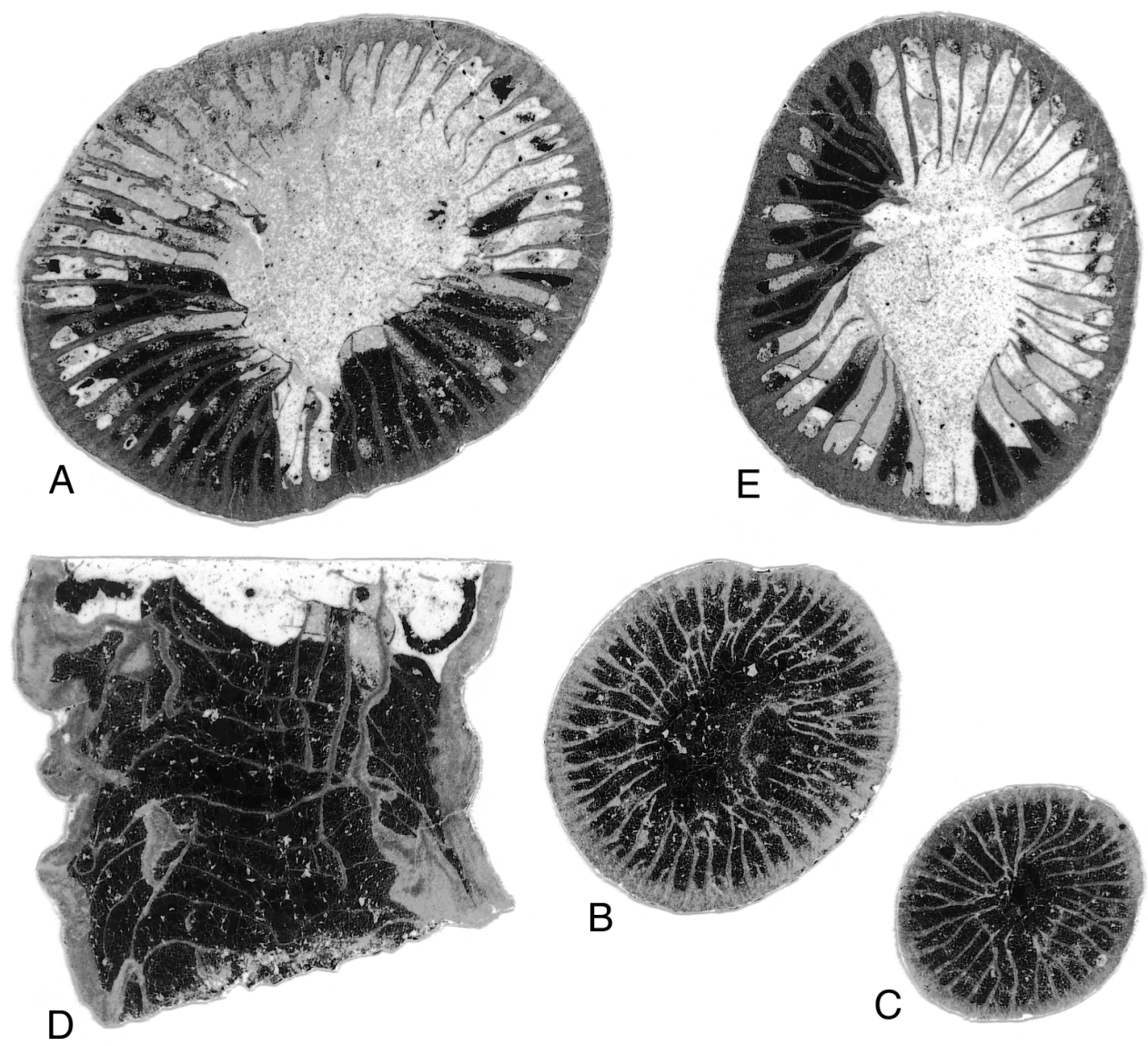

\section{Explanation of Plate II}

Figs. A-E. Fosselasma unicum (Neuman, 1975). A-D, RM Cn 2507, holotype. The transverse sections A-C are showing thin major septa withdrawn from axis, short minor septa, and the narrow stereozone in the ephebic and neanic stages. D, longitudinal section showing the tabularium in the ephebic stage. E, RM Cn 59327. Transverse section at the bottom of the calice showing the pronounced septofossula with the characteristic short cardinal septum (also seen in $\mathbf{A}$ in a somewhat earlier stage). Both specimens derive from the Upper Ordovician Loka Formation (Hirnantian); Borenshult, Östergötland, Sweden. All figures are enlarged $\times 3$ and re-figured from Neuman (1975, fig. 15B-F). Cardinal side oriented downwards in all transverse sections. 
1975, pp. 357, 358) are most similar to Fosselasma unicum, showing only minor variation (specimens from Kullsberg are provided with tabulae with more concave central parts, and specimens from Nittsjö with more irregularly twisted septa). Unfortunately, no more specimens have been collected from these localities, and the original specimens (stored in the Palaeontological Museum, University of Uppsala) were not available for the present study.

Occurrence. Fosselasma unicum (Neuman, 1975) is currently found in the Hirnantian Loka Formation (erected by Bergström \& Bergström 1996, and earlier called Dalmanitina beds) from the locality Råssnäs (earlier named Råsnäs) and probably from the same formation at Borenshult (this locality is no longer available). Fosselasma cf. unicum derives from corresponding strata in the Siljan District from the localities Kullsberg and Nittsjö.

\section{SUMMARY AND CONCLUSIONS}

The new streptelasmatid genera Eurogrewingkia gen. nov. and Fosselasma gen. nov. are here erected and their type species viz. Grewingkia bilateralis Neuman, 1969 and Streptelasma unicum Neuman, 1975 are briefly re-described. The appearance of these new genera in late Ashgillian times is a result of environmental changes, including sea level changes and temperature alterations due to glaciation and deglaciation episodes, shaping new habitats (Brenchley 1984).

In late Ordovician Rawtheyan times, the rugose coral fauna in Baltoscandia was dominated by species of non-fossulate streptelasmatid genera, e.g., Streptelasma Hall, Bodophyllum Neuman, Borelasma Neuman, and Helicelasma Neuman. Streptelasmatid genera with a cardinal fossula sensu stricto increased sparsely in the late Rawtheyan, e.g., Grewingkia kiaeri (Wedekind, 1927) in Norway. Grewingkia europaea europaea (Roemer, 1861), G. europaea hosholmensis Kaljo, 1961, Grewingkia buceros (Eichwald, 1856 (age somewhat uncertain) are found in Estonia in Pirgu beds. Grewingkia contexta Neuman, 1969 and few undescribed species of Grewingkia and Kaljolasma are also found in Sweden in the Boda Limestone.

In Europe species of Eurogrewingkia gen. nov. appeared during late Rawtheyan or early Hirnantian times, represented by Eurogrewingkia bilateralis (Neuman, 1969) from the upper part of the Boda Limestone in Sweden, of the Chair of Kildare Limestone, and probably of the Portrane Limestone in Ireland and the Conway Castle Grit of Conway, Wales, U.K. Eurogrewingkia anguinea (Scheffen, 1933) is found in Rawtheyan (5a) beds in the Oslo Region, Norway.

The North American Ashgillian species, which here are assigned to Eurogrewingkia, are Eurogrewingkia callahanensis (Elias, 1984) and E. penobscotensis (Elias, 1982), known from the Penobscot County in Maine (Elias 1982), and the eastern Klamath Mountains (Elias \& Potter 1984) and northern Sierra Nevada (Elias et al. 1994) in California. 
In Hirnantian times species of Fosselasma gen. nov. appeared, viz. F. unicum (Neuman, 1975) from the Loka Formation in Sweden and Fosselasma sp. nov. from beds $5 b$ in Norway. Also species of several other streptelasmatid septofossulate genera appeared, e.g., Ullernelasma, Rhegmaphyllum, and Dalmanophyllum, the last two genera being also present in the Early Silurian. Streptelasmatid species with a fossula sensu stricto are rare. Kaljolasma giganteum (Kaljo, 1958) is described from Porkuni beds in Estonia.

\section{ACKNOWLEDGEMENTS}

I am greatly indebted to Dimitri Kaljo and Jan Bergström who read and made valuable comments on this manuscript. Robert Elias (acting as referee) thoroughly read the manuscript and gave most valuable scientific advise and corrected my English. I am also most grateful to the Estonian Academy of Sciences and the Norwegian Academy of Sciences and Letters for generous financial support for my visits and field excursions in Estonia, where necessary studies of type material of Lower Palaeozoic rugose corals could be done. Most of the research for this paper was done at the Geological Institute, University of Bergen. Special thanks are due to Greger Solend for making peel- and thin sections and for necessary photographic darkroom work.

\section{REFERENCES}

Bergström, S. M. \& Bergström, J. 1996. The Ordovician-Silurian boundary successions in Östergötland and Västergötland, S. Sweden. Geol Soc. Sweden (GFF), 118, $25-42$.

Billings, E. 1858. New genera and species of fossils from the Silurian and Devonian formations of Canada. Canadian Nat. and Q. J. Sci., 3, 419-444.

Billings, E. 1862. On some new species of fossils from the Québec group. Geol. Surv. Canada, Palaeozoic Fossils, 1, 57-185.

Brenchley, P. J. 1984. Late Ordovician extinctions and their relationship to the Gondwana glaciation. In Fossils and Climate (Brenchley, P. J., ed.), pp. 291-315. John Wiley \& Sons.

Duncan, H. 1957. Bighornia, a new Ordovician coral genus. J. Paleont., 31, 607-615.

Dybowski, W. 1873. Monographie der Zoantharia sclerodermata rugosa aus der Silurformation Estlands, Nord-Livlands und der Insel Gotland. Archiv Naturkunde Liv-, Ehst- und Kurlands, Ser. I, 5, 257-414.

Eichwald, E. 1856. Beitrag zur geografischen Verbreitung der fossilien Thiere Russlands. Alte Periode. Bull. Soc. Nat. Moscou, XXIX.

Elias, R. J. 1981. Solitary rugose corals of the Selkirk Member, Red River Formation (Late Middle or Upper Ordovician), southern Manitoba. Geol. Surv. Canada, Bull., 344, 1-53.

Elias, R. J. 1982. Latest Ordovician solitary rugose corals of eastern North America. Bull. Amer. Paleont., 81, No. 314.

Elias, R. J. 1985. Solitary rugose corals of the Upper Ordovician Montoya Group, southern New Mexico and westernmost Texas. J. Paleont., 59, pt. II. Paleont. Mem., 16.

Elias, R. J. \& Potter, A. W. 1984. Late Ordovician solitary rugose corals of eastern Klamath Mountains, northern California. J. Paleont., 58, 1203-1214.

Elias, R. J., Potter, A. W. \& Watkins, R. 1994. Late Ordovician rugose corals of the northern Sierra Nevada, California. J. Paleont., 68, 164-168. 
Hall, J. 1847. Natural history of New York, Part VI, Paleontology of New York 1, 1-338. Albany.

He [Ho] Xin-Yi, 1978. Tetracoral fauna of the Late Ordovician Guanyinqao Formation, Bijie, Guizhou Province. Chinese Acad. Sci. Professional Pap. Stratigraphy, Palaeontology, 6, 1-45.

Hill, D. 1981. Rugosa and Tabulata, Vols. 1 and 2. In Treatise on Invertebrate Paleontology, Part F; Coelenterata; Supplement 1 (Teichert, C., ed.), pp. 1-762. Geological Society of America and University of Kansas.

Kaljo, D. 1958. Some new and little-known Baltic tetracorals. ENSV TA Geol. Inst., Uurimused, 3, 101-123 (in Russian).

Kaljo, D. L. 1961. Some additional data on the study of Ordovician streptelasmid in Estonia. ENSVTA Geol. Inst. Uurimused, 6, 51-67 (in Russian).

Kaljo, D. \& Klaamann, E. 1965. The fauna of the Portrane Limestone, III. The corals. Bull. Brit. Mus. (Nat. Hist.). Geol., 10, 416-434.

Lindström, G. 1880. In Angelin, N. P. \& Lindström, G. Fragmenta Silurica. Kungl. Svenska Vetensk. Akad. Stockholm.

McAuley, R. J. \& Elias, R. J. 1990. Latest Ordovician to earliest Silurian solitary rugose corals of the East-Central United States. Bull. Amer. Paleont., 98, 1-82.

Nelson, S. 1963. Ordovician paleontology of the northern Hudson Bay Lowland. Geol. Soc. Amer., Mem., 90.

Neuman, B. 1969. Upper Ordovician streptelasmatid corals from Scandinavia. Bull. Geol. Instns. Univ. Uppsala, New Ser., 1, 1-73.

Neuman, B. E. E. 1975. New Lower Palaeozoic streptelasmatid corals from Scandinavia. Geol. Fören. Stockh. Förhandl., 55, 335-359.

Neuman, B. E. E. 1984. Origin and early evolution of rugose corals. Palaeontographica Americana, 54, 119-126.

Neuman, B. E. E. 1986. Rugose corals from the Upper Ordovician erratic boulders of Öland. Geol. Fören. Stockh. Förhandl., 108, 349-365.

Neuman, B. E. E. 1993. Taxonomic reliability of morphological structures in rugose corals. Cour. Forsch.-Inst. Senckenberg, 164, 119-125.

Neuman, B. E. E. 1997. Evaluation of rugose coral potentials as index fossils. Bol. R. Soc. Esp. Hist. Nat. (Sec. Geol.), 92, 303-309.

Neuman, B. E. E. 1998. The latest Ordovician rugose corals in Baltoscandia. In Working Group on Ordovician Geology of Baltoscandia (WOGOGOB), Bornholm 1994 (Stouge, S., ed.), pp. 93-99. Danmarks og Grønlands Geol. Unders. Rapport 1996/98.

Nicholson, H. A. 1889. In Nicholson, H. A. \& Lydekker, R. A Manual of Palaeontology for the use of Students, 3rd Edition. William Blackwood and Sons, Vol. 1, pp. 1-885, Vol. 2, pp. 886-1624.

Roemer, F. 1861. Die fossile Fauna der Silurischen Diluvial-Geschiebe von Sadewitz bei Oels in Nider-Schlesien. Eine Palaeontologische Monografie. Breslau.

Savage, T. E. 1913. Stratigraphy and paleontology of the Alexandrian Series in Illinois and Missouri; Part 1. (Pre-print of III. State Geol. Surv. Bull., 1917, 23, 67-160).

Scheffen, W. 1933. Die Zoantharia Rugosa des Silurs auf Ringerike im Oslogebiet. Det Norske Vidensk.-Akad. Skrifter, Mat.-Naturv. Kl. 1932, 5, 1-64.

Scrutton, C. T. 1971. Palaeozoic coral faunas from Venezuela, I. Silurian and Permo-Carboniferous corals from the Merida Andes. Bull. Br. Mus. Nat. Hist. Geol., 20, 183-227.

Somerville, I. D. 1996. Cnidarians. In Fossils of the Upper Ordovician (Harper, A. T. \& Owen, A. W., eds.). Palaeont. Assoc. Field Guides to Fossils, 7, 32-48.

Thorslund, P. 1935. Über den Brachiopodenschiefer und den jüngeren Riffkalk in Dalarne. Nova Acta Regio Societatis Scientiarum Uppsaliensis, ser. IV, 9, No. 9.

Wedekind, R. 1927. Die Zoantharia Rugosa von Gotland (bes. Nordgotland). Sver. Geol. Unders., Ser. Ca, 19, 1-94.

Whiteaves, J. F. 1896. Description of eight new species of fossils from the (Galena) Trenton limestones of Lake Winnipeg and the Red River valley. Canadian Rec. Sci., 6, 387-397. 


\section{Uued varapaleosoiliste rugooside perekonnad Eurogrewingkia gen. nov. ja Fosselasma gen. nov.}

Björn E. E. Neuman

On püstitatud kaks uut rugooside perekonda. Eurogrewingkia gen. nov. (tüüpliigiks valiti Grewingkia bilateralis Neuman, 1969) hõlmab streptelasmatiidseid koralle, mille ontogenees on Grewingkia oma laadi, kuid neil puudub kardinaalfossula. Neid on leitud Euroopa ja Põhja-Ameerika Ülem-Ordoviitsiumi ülemisest osast (Rawtheyan-Hirnantian). Teine perekond Fosselasma gen. nov. (tüüpliik Streptelasma unicum Neuman, 1975) ühendab Streptelasma laadi ontogeneesi ja kardinaalse septofossulaga rugoose. Seni on neid teada vaid Rootsi ja Norra Hirnantianist. 